\title{
電子ジャーナルー部売りの動向
}

\author{
原田英二 ${ }^{1}$, 渡辺怜子 ${ }^{2}$, 児嶋紀子 ${ }^{1}$, 水野 充 $^{1}$ \\ 著者抄録 :インターネット時代の到来により, 電子ジャーナル出版は加速され, 学術雑誌の世界では \\ 一般的なものとなってきた。電子出版には従来の冊子体べースの出版物にはないさまざまなメリッ \\ トが見られるが, 電子化により, 雑誌に縛られない, 論文単位での扱いが容易となった点もそのひ \\ とつである。そして, それに応じて論文の個別売り, いわゆる一部売りサービスが登場してきた。一 \\ 部売りサービスによる論文の購入は，出版社だけでなく，アグリゲータ，二次データベース経由に \\ よっても可能となってきている。ここではそれら一部売りを扱う業者を出版社, アグリゲータ，二 \\ 次データベースサービスに分けて整理し, それぞれの特徵をまとめた。さらに, 提供業者ごとの価 \\ 格を調査し，比較を行った。 \\ キーワード : 電子ジャーナル, 一部売り, 出版社, アグリゲータ, 二次データベースサービス
}

\section{Trends in pay-per-view of electronic journals}

\author{
HARADA Eiji'; WATANABE Reiko²; KOJIMA Noriko'; MIZUNO Mitsuru'
}

\begin{abstract}
Author Abstract: Electronic journal publication, speeded up by the advance of the Internet age, became common in the world of the academic journals. Among the various advantages of electronic journals against journal publication in traditional print style, there is a large point that the binding of issues has nearly vanished that we can now easily handle journals by each article. Accordingly, sales by single articles, called such as pay-per-view, have appeared. Services by pay-per-view are also becoming available at sites other than publishers. We have assorted those pay-per-view services into three groups by supplier, i.e. publishers, aggregators and secondary database services, and illustrated out the characteristics of their services. Furthermore, brief analysis on cost performance is given.
\end{abstract}

Key words: electronic journal, pay-per-view, publisher, aggregator, secondary database service

\section{1.はじめに}

インターネットの普及によって, 出版社, 学協 会が発行する雑誌の目次や抄録の無料公開サービ ス, 論文フルテキストの提供等, インターネット を経由した電子ジャーナルサービスは急速に発展 している。

電子ジャーナルは 1) 冊子体と比較し, 速報性 に優れている 2) リンク機能により引用, 関連文 献への参照が容易である 3) 冊子体ではできない 3次元や動画での表現も可能である 4) 冊子体のよ
うに保管場所をとらない 5) 検索機能を有してお り, 検索結果からの外部データへのリンクも可能 である, といった特性があり, 今後サービスが拡 大していく可能性は大きい。その一端として, 定 期購読が主流だった電子ジャーナルサービスサイ トに, 論文一部売りという機能が多くのサイトで 見られるようになった。今回はこの電子ジャーナ ル一部売りに注目し, 出版社Webサイト, アグリ ゲータ（複数出版社の電子ジャーナルを包括的に 提供するサービス)，二次データベースを対象に論 文一部売り提供内容について調査を行った。

1科学技術振興事業団＼cjkstart情報調整室（干102-8666 東京都千代田区四番町5-3） Tel. 03(5214)8402 E-mail: eharada@jst.go.jp ${ }^{1}$ Japan Science and Technology Corporation, Department of Planning and Coordination of Office of Science and Technology Information (5-3, Yonbancho, Chiyoda-ku, Tokyo, 102-8666)

2科学技術振興事業団＼cjkstart製品管理部（广102-8666 東京都千代田区四番町5-3）Tel. 03(5214)8411

${ }^{2} J a p a n$ Science and Technology Corporation, Department of Products Management (5-3, Yonbancho, Chiyoda-ku, Tokyo, 102-8666) 


\section{2. サービスの概況}

\section{1. 調査内容}

手始めに, 次のような項目についてホームペー ジ掲載内容を中心に調査を行った（表1〜表3）。へ ルプやQ\&A等で見当たらなかった事項については, 部分的にしか記載できていないものもあるが, ご 容赦いただきたい。また, 数值等は2002年12月時 点のものである。

一部売りは，一般に電子ジャーナルサイトなど の付加価值として提供されているので, まずその サイト全体について, 名称, URL, 提供団体名, サ一 ビス概要をまとめ, 業種を大まかに分類した。業 種のうち, アグリゲータ等は旧来の購読代理店や 複写業者が相互に業態を拡張してきているため, 明確には分けづらい部分であるが, 便宜的に複写 サービス由来のものをDDS, その他, 購読代理店 等に端を発するものをアグリゲータとして記載し た。一部売りサービス名から下の欄は, 一部売り に限定した内容となっている。一部売りサービス 名は,特に命名されているものもあるが, single article sales といったpay-per-viewとは異なる記載も見られ たため, 参考として挙げた。対象誌数は, 特に一 部売りを利用できる誌数を記載したので, サイト 全体で扱う雑誌数より少ないことがある。

全文アクセス方法としては, 大きく分けてサイ 卜内のインフラを利用した検索や目次の閲覧，ま た, 外部のデータベース検索結果などから一部売 り提供サイトへのリンクがあるが, 外部からのリ ンクについてはごく一部を調べただけで, 他から もたくさんリンクされているので参考までとして ほしい。目次で「ブラウズ」としているのは，検 索ではなくディレクトリ形式で探せるものである。 また, 最下段の外部リンク等には, 購入した文献 記事の引用などから他の文献にリンクが張られて いる場合について記載している。

提供形態と課金関連については, 2.2節以降を参 考にしてほしい。なお, ユーザ登録とクレジット 番号の扱いが似た闌となっているが, ユーザ登録 はそのサイト（またはクッキー）に記憶される情 報であるのに対し, クレジット番号については多 くのサイトで都度入力させる（記憶しない）形式 となっていたので，あえて闌を分けた。

各サービスの詳細は表1〜3に掲載したが, その 傾向を以下にまとめる。

\section{2. 出版社}

オンラインジャーナル提供が軌道に乗った出版 社は,急なニーズの生じた顧客などへの補助的サー ビスとして一部売りを投入してきている。ただし， Springer Verlagのように, 年間購読契約に重点を置 いて, 一部売りには手を染めていない出版社もま だある。

一部売りを行っている出版社は, 基本的に個人 向けクレジット決済でサービスを行っており, 多 くは氏名とメールアドレスの登録を要求する。ま た, すべての雑誌が一部売りで利用できるわけで はない出版社が多い。この場合, 雑誌一覧などで

一部売りの可否が示されている。

記事へは購読者と同様のアクセスが解放されて いる場合もあるが,PDFの利用だけに限られ, HTML 版で提供されている引用リンクなどが利用できな い場合もある。また, 出版社サイトの記事データ ベースの利用が購読ユーザに限定されていること もある。利用量の減少を理由に購読から切り替え ることを検討する場合は注意が必要である。抄録 表示までの目次の閲覧（TOCブラウズ）は, 通常 ゲストユーザでも利用できる。目次や抄録画面で 全文表示（full text）を選択した場合，また，他の データベースや文献の引用など外部からリンクし てくる場合には，IP認証が設定されていなければ パスワード入力の画面が表示されるが, その片隅 に一部売り機能へのリンクがあることが多い（図 1）。逆に「一部売り」といったメニューから記事 を選びに行くサービスは少ないので, 一部売りが あるかよくわからない場合は，とりあえず全文へ のリンクをクリックしてみるとよい。

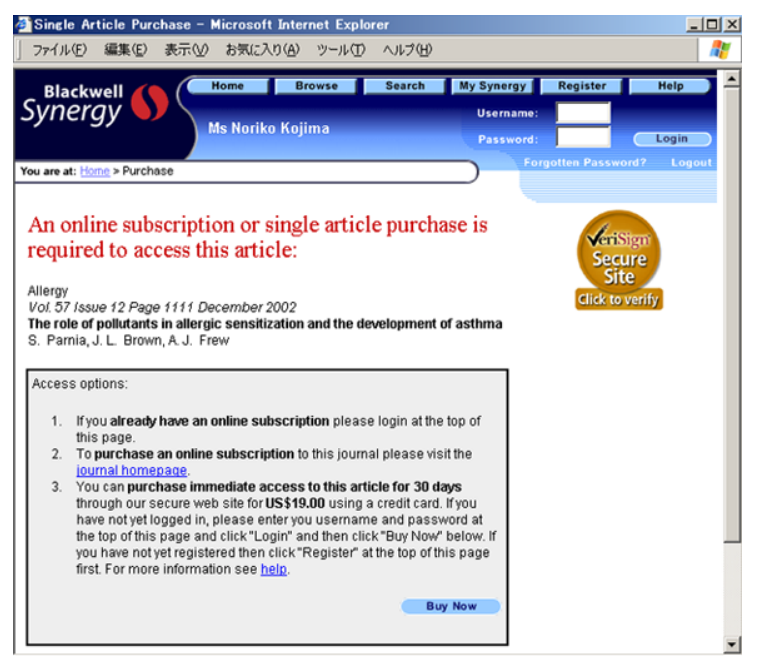

図1 Synergy論文購入選択画面 
通常このような一部売りでは, 許可された期間 中なら何回でも再閲覧が可能である代わりに，ア クセスできる期間が短く制限されている。数千円 支払った権利が24時間程度で切れてしまう場合も あるので, 忘れずに手元へ保存したり, プリント アウトしたりする必要がある。商業出版社では, 一律料金で1部当たり\$20〜30という価格付けがよ く見られるが, KargerやNatureのようにページ数や 記事タイプで価格が変化する場合もある。学会系 出版社も基本的に同じであるが, 商業出版社には 見られない安価（\$5〜10程度）で提供している例 も多い。商業出版社はあくまで購読契約を中心と しているのに対し，学会系出版社では一部売りを 「読者を広げる武器」として位置づけていると考え られる。

出版社の中で, 全文入手経路の豊富さで目立つ たのが, 米国物理会 (AIP) である。AIPのサイト から利用できるサービスだけでも, 表1の 2 種類が ある。a.は他社で見られるような通常の一部売り であるが, さらに同じ申し込み画面で外部ドキュ メントデリバリーサービス（後述のInfotrieve）の利 用が選択できる。b.に示したパック販売は, 特定の 雑誌について, 1 年間有効のアクセス権を 12 部また は25部の単位で割安で購入することができる。有 効期限内に買い足していくと, 過去の記事へのア クセス権がずっと保持される仕組みになっており， その分野で頻繁に利用するユーザにとっては非常 にお買い得な仕組みである（図2）。

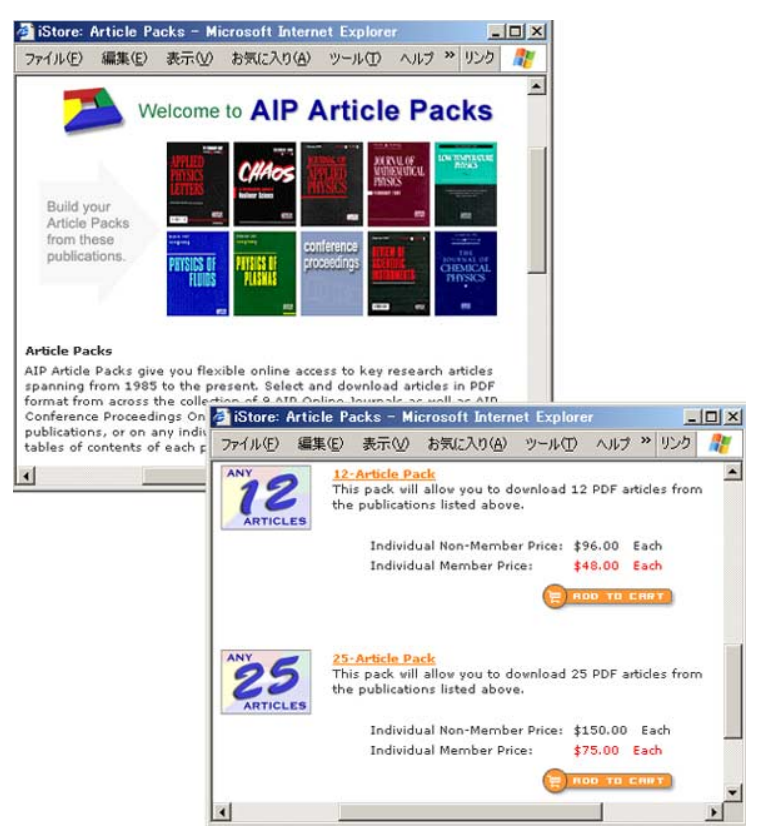

図2 AIP Article Packs

\section{3. アグリゲータ等}

アグリゲータ等では, いくつかの提供パターン が存在する。1つは課金の取りまとめだけを行い, 出版社サイトの文献ヘリンクさせるもの, もうひ とつは電子メールでPDFファイルを送付するもの, さらには, ファイルをダウンロードするためのリ ンクを電子メール等で示すものなどである。後 2 者 では, 一部売りというよりは, 従来の複写サービ スが電子化されたものという色合いが強く, 電子 配信ができないときには郵送やFAXによる複写に 切り替えて対応するものもある。また, 一定のア クセス期間が表示されていても,それとは別に1回 しかダウンロードが許可されないもの (表2で初回 参照のみとあるもの) もあるので, 利用方法をよ く理解しておく必要がある。多くは出版社と同じ くクレジットで支払いを受け付けるが, サイトに よっては預託金または請求によるアカウントを設 けることも可能である。また,アグリゲータによっ てカバーしている範囲が異なるものの, 複数の出 版社からの文献をまとめて入手することができる ため, 利便性が高い。

購読代理店であるSwetsBlackwellやEBSCOから提 供されているサイトでは, 購読を補完する機能と して, 一部売りで文献を入手するための経路を提 供している（Swets自身では一部売りの課金の処理 は一切行わず出版社側のサービスに誘導するだけ であるため, 利用者側の課金管理が煩雑になるか もしれないが, その分利用できる誌数が多いと思 われる)。また, ドキュメントデリバリーを主体と するIngentaやInfotrieveは購読誌の登録機能を持つ ことにより, 統一的なフルテキスト利用環境を実 現し, 総合サイトへと発展してきている。いずれ も購読誌への全文リンク機能と一部売り機能を併 せ持つことで, より無䭾な出費の少ない文献利用 を提案している。今後これらのサイトは, ますま す他サイトの長所を取り入れ, 新たな機能も投入 して，しのぎを削っていくものと思われる。

また, HighWireは電子出版システムと検索プラッ トフォームを提供することで, 学会などの中小団 体のものを中心に多数の雑誌を扱っている。年間 購読管理機能のほかに一部売りの課金機能も用意 されているため, これを利用して積極的に読者層 を広げようとする雑誌が多く, 商業出版社に比べ, 数分の一の価格（\$5〜10）で販売している例も少 なくない。課金等の実施は各出版団体で管理して いるので,この面でHighWireは独立した出版社の 集合体とも呼べ,一部売りの提供形態も出版社に 


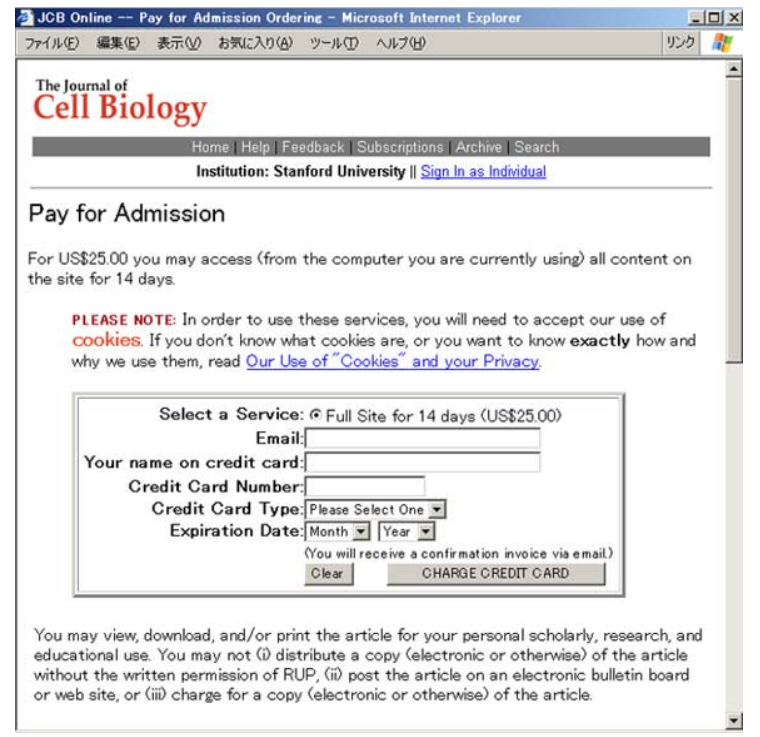

図3 HighWire雑誌単位購入画面

よく似ている。HighWireの一部売り機能では, 文 献一記事のほかに, 雑誌丸ごとの短期閲覧権も扱 えるため, 1週間から1か月に限って非常に安価に 利用することができる雑誌もある（図3）。アグリ ゲータとしてのHighWireの強みは, 多様な雑誌を 取りまとめる中で誕生した被引用文献のリンク機 能であろう。HighWire参加誌どうしという制約は あるものの, 一部売り機能と併せて利用すること で，発行済みの論文がどのように他者に注目され ているかを幅広く追跡することができる。

\section{4. 二次情報サービス}

二次情報サービスでも, その検索結果から原文
献 (電子ジャーナル) にリンクさせる機能が広まっ ており,その拡張として一部売りにも参入するサー ビスが出てきた（図4）。通常, 案内料は特に要求 されず, 出版社提示の価格で購入する形となる。 データベース利用料と合算して請求するサービス もあるため, 改めて支払い手続きを取ることもな く気軽に利用することができる。データベースの 検索結果からその場で全文を表示させる利用形式 の場合, 再度参照するための仕組みがないことが 多いので, その場で忘れずに保存や印刷を行う必 要がある。一般にアグリゲータと同様のサービス 形態が多いと言える。検索サービスによっては, まだ文献申し込みのインタフェースが検索機能と 融合しきっていないために書誌情報のコピー\&ペー スト程度の手間がかかることもあるが，これも時 間の問題で改善されていくものと思われる。

\section{3. サービス料金の比較}

\section{1. 調査内容}

これまで述べてきたとおり, 論文の一部売りの 購入手段は多様であり, 提供価格およびその体系 はサービスによってさまざまである。また, 一部 売りの存在は, ユーザにとって雑誌を定期購読す べきか否かという判断に直面させるものでもある。 そこで, ここでは代表的な出版社をピックアップ し, 定期購読と一部売りによる価格の比較と, 一 部売りサービス間との比較とを行った（表4）。た だし, 前述のとおり各一部売り提供サービス, 出 版社による定期購読によって受けられるサービス に相違があり, 提供価格は購入手段決定のための

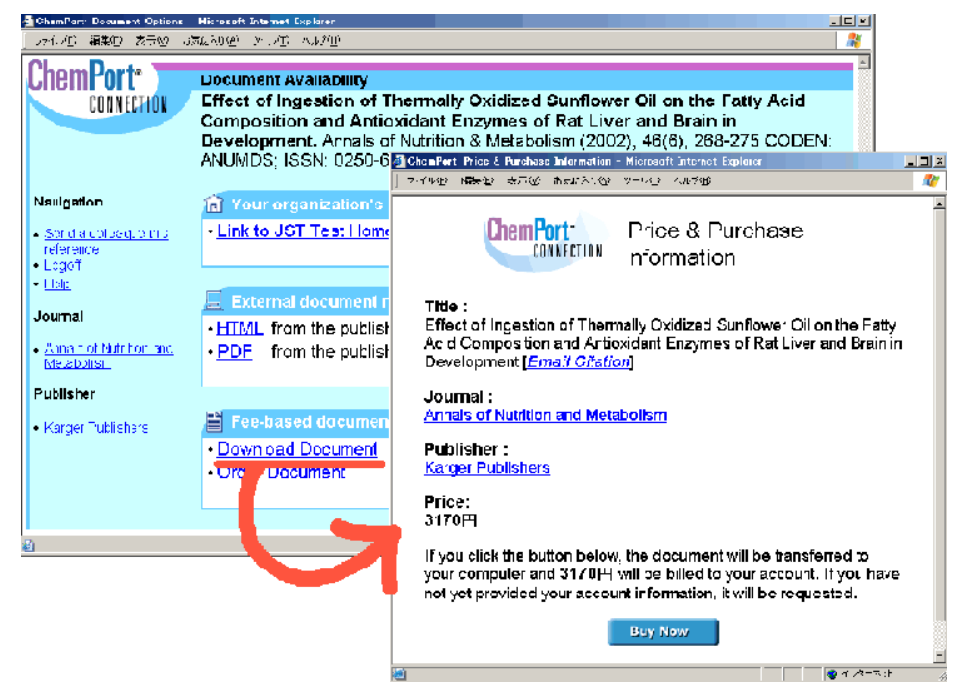


一要素にすぎない。

\section{2. 調查方法}

料金比較のための各数值は, サービスを提供す る業者のWeb上で表示されている金額（ドルまた はポンド表示のものは120.5円／ドル, 190.5円／ポ ンドで換算）を基に, 次の方法で算出した。

・ 年間購読料一出版社が提示する法人年間購読料 金 (学会誌等で会員, 非会員の別がある場合は 非会員価格）を採用。

・年間購読料論文単価一年間購読料を基に, JOIS （JICSTファイル）に登載されている1999２001 年までの論文数を年間平均した数（JOIS年間平 均登載論文数）により単価を算出。なお, JICST ファイルに登載される論文はJSTの採択基準によ

り巻頭言等の論文記事ではないものは採択して いないため, 実際に雑誌に登載されているもの よりも少ないことをお断りしておく。

・年間購読料金 /一部売り料金

年間購読料を出版社が提示する一部売り料金に より割り, 年間購読料金分で参照可能な一部売 り購入論文数を算出。

\section{3. 比較結果}

まず，算出した年間購読料論文単価について見 ると, 出版社によってある程度単価の統一性が見 られる。最も安い単価設定となるのがAIPであり, 代表的な雑誌 (Applied Physics Letters, Journal of Applied Physics）はいずれも年間購読料としては決 して安いものではないが, 年間の論文数が多く, 結果として単価は最も安い設定となっている。一 方で, Karger, Kluwerは年間論文数が少なく, 単価 が高くなっている。Natureの雑誌については, 商業 誌的な色合いが強く, News記事といったJOISでは 採択されていないものが他誌に比べて多い。した がって年間登載論文数は本来はより多くなるはず である。にもかかわらず, 年間購読料論文単価は 他社のものと比べて遜色ない結果となった。

次に, 出版社およびその他業者の一部売り料金 設定について見てみると, いずれの雑誌も当然な がら出版社が提示する一部売り価格が最も安価な ものとなった。出版社を除くとChemPort, Ingenta, Infotrieve という順でお買い得感が見られるが, ChemPortは一部売りを扱う対象誌が少なく, 一方, 価格的には高いものの, Infotrieveが最も多くのコ ンテンツを提供できると言える。

また, 一部売りについて最も慎重な姿勢を見せ
ているのがElsevierであり, 調査した対象誌につい て見ると,自社で一部売りを提供する以外はIngenta からScienceDirectへリンクさせる（したがって，一 部売り価格はScienceDirectの一部売り単価3,615円 (\$30)）のみとなった。

そして最後に, 年間購読料金で参照可能な一部 売り購入論文数を算出してみた。これにより定期 購読と一部売り購入のコスト面からの考察が可能 となる。例えばApplied Physics Lettersを見ると97件 となっており, これより多くの論文を年間で参照 するのであれば定期購読した方がよいと見ること ができる。全体的に見ると, 一部売り購入の方が 得になる件数は200件以下となり, JOIS年間平均登 載論文数と比較すると, 論文数が多い雑誌につい ては年間購読した方がbetterであるとの判断ができ る（論文数が多い雑誌でも, 目次などの無料参照 可能な部分をブラウジングするのみで本文まで参 照することが少ないという場合はその限りではな い)。また一方で, 一部売りと法人年間購読契約の 大きな違いとして, 一部売りは個人での利用に限 定される点がある。したがって, 同一法人内で異 なる人が同じ論文の全文を参照したい場合でも， 一部売りでは別々に購入しなければならないため, 単純に年間論文数と比較すればよいということに もならないことに注意が必要である。すなわち, 各雑誌が法人内でどれくらいの需要を持っている かという判断を加味して検討しなければならない ことになる。

\section{4. 終わりに}

以上述べてきたとおり, 電子ジャーナルの流通 により登場してきた一部売りサービスについて概 観したが, 市場規模としてはまだまだ定期購読に 及ぶものではない。出版社の意識としても一部売 りサービスは「論文を入手するための最後の手段」 であり, 依然として定期購読を主眼に置いている。 しかしながら, 今回はそこまで詳細に紙面を割く ことができなかったが, 出版社サイドとしては一 部売り販売した雑誌論文のセキュリティの問題, ユーザサイドとしては法人として一部売り購入に どのように対処するか(多くのサービスはクレジッ トカード決済であるため, 法人として対応するこ とが難しい）といった一部売りの障壁を取り除く 技術またはビジネスモデルが流通することにより， 市場規模は大きく拡大する可能性を秘めている。 今後の動向に注目していく必要がある。 
表1-1 出版社の一部売りサービス

\begin{tabular}{|c|c|c|c|c|c|c|c|c|c|c|c|c|c|c|c|c|c|c|c|c|}
\hline 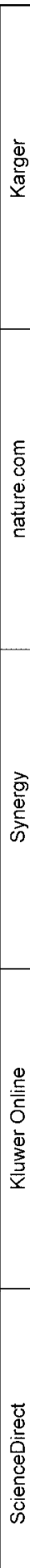 & 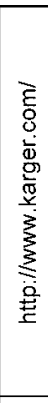 & 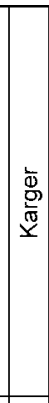 & & 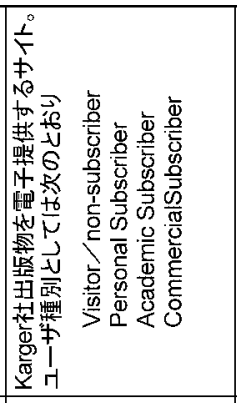 & 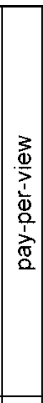 & 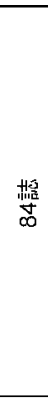 & 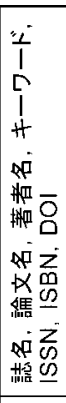 & 0 & $\begin{array}{l}\text { D } \\
\sum_{0}^{\mathbb{D}} \\
\text { D. } \\
0\end{array}$ & 0 & 01 & 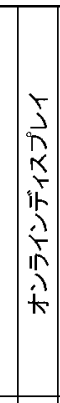 & 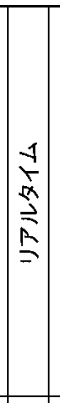 & $\begin{array}{c}\text { 監 } \\
\text { 蓝 } \\
\text { 品 }\end{array}$ & 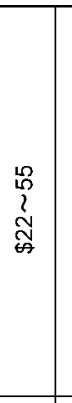 & $\stackrel{1}{\grave{\lambda}}$ & 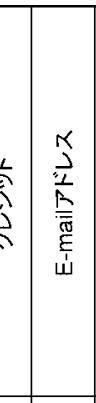 & 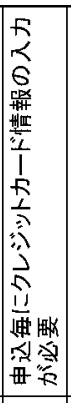 & 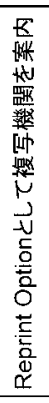 & 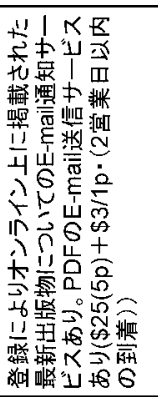 \\
\hline 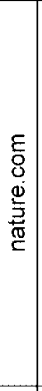 & 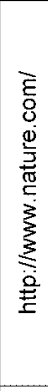 & 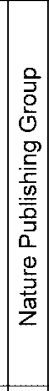 & 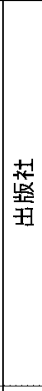 & 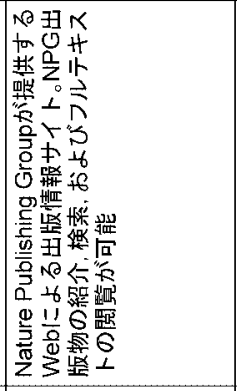 & 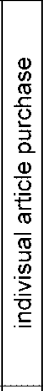 & 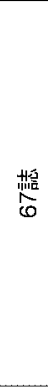 & 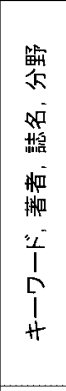 & 0 & $\begin{array}{l}\frac{D}{0} \\
\sum_{0}^{0} \\
0 \\
0\end{array}$ & 0 & 0 & 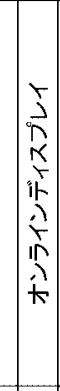 & 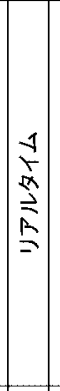 & $\stackrel{\text { 묘 }}{\sim}$ & 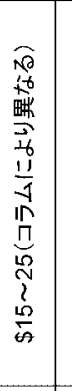 & $\stackrel{1}{\stackrel{1}{\hat{\Omega}}}$ & 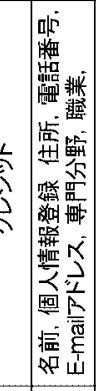 & 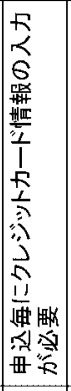 & $\begin{array}{l}\text { 覓 } \\
\text { k }\end{array}$ & 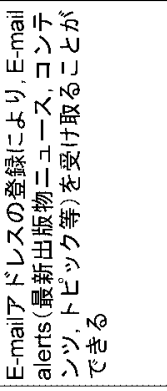 \\
\hline $\begin{array}{c}\text { Dे } \\
\stackrel{\overrightarrow{0}}{\overrightarrow{0}} \\
\text { के }\end{array}$ & 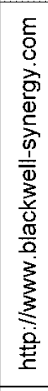 & 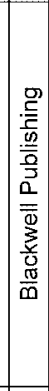 & 蕉 & 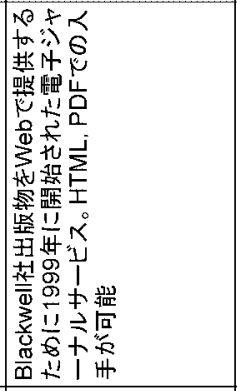 & 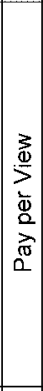 & 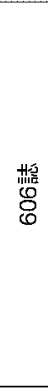 & 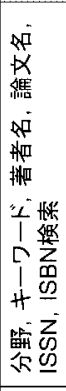 & 0 & 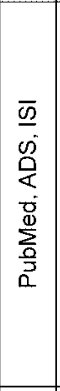 & O & 0 & 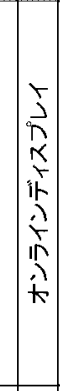 & 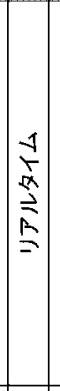 & 号 & $\stackrel{\sigma}{\dot{s}}$ & 络 & 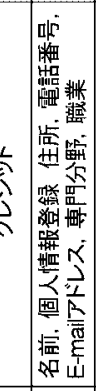 & 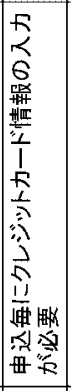 & 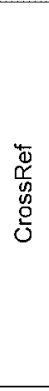 & 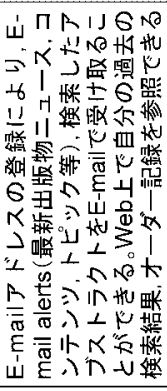 \\
\hline 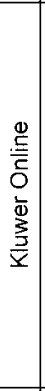 & 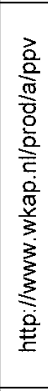 & 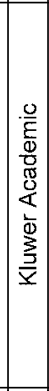 & 藋 & 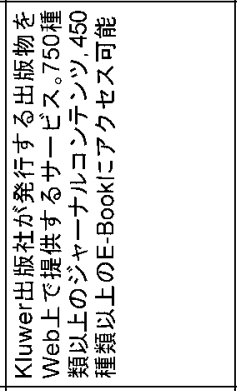 & 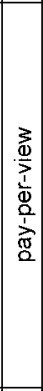 & $\begin{array}{l}\text { 嘗 } \\
\text { 品 }\end{array}$ & 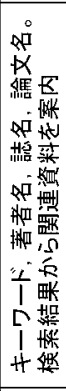 & 0 & 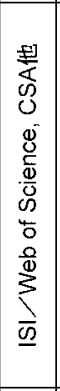 & 0 & $x$ & 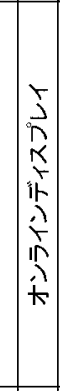 & 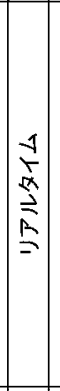 & 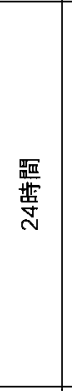 & 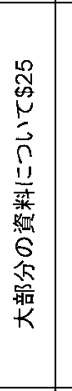 & $\stackrel{1}{\grave{\lambda}}$ & 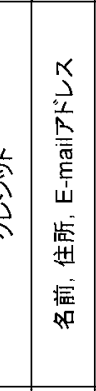 & 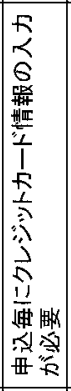 & $\begin{array}{l}\text { 畐 } \\
k\end{array}$ & 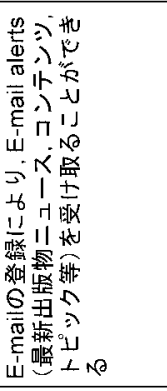 \\
\hline 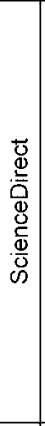 & 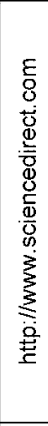 & 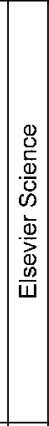 & 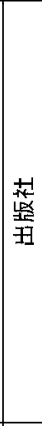 & 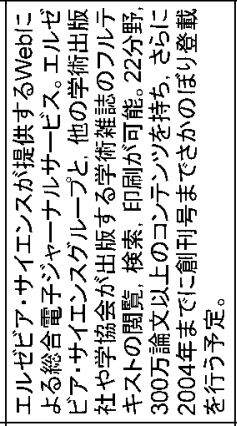 & 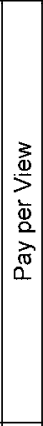 & 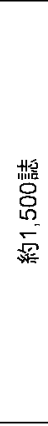 & 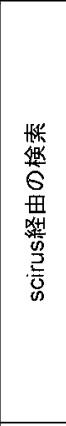 & 0 & $\begin{array}{l}\text { D } \\
\sum_{0}^{\infty} \\
\frac{0}{3} \\
0\end{array}$ & o & 0 & 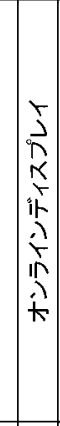 & 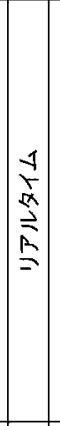 & 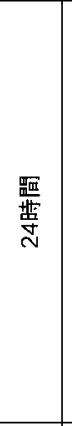 & 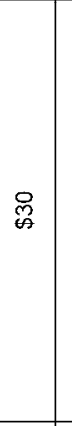 & ถ્ડ & 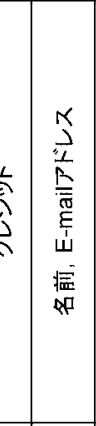 & 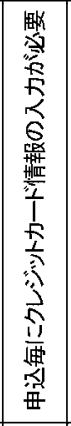 & 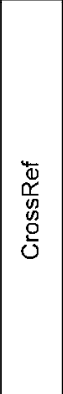 & 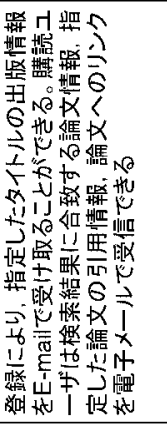 \\
\hline \multirow[t]{2}{*}{ 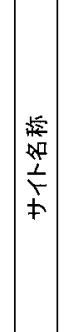 } & \multirow[t]{2}{*}{$\begin{array}{l}\vec{\alpha} \\
\frac{\vec{\alpha}}{2} \\
\frac{a}{1}\end{array}$} & \multirow{2}{*}{\multicolumn{2}{|c|}{ 选 }} & \multirow[t]{2}{*}{ 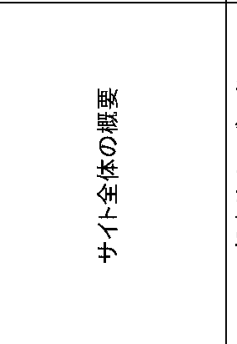 } & \multirow[t]{2}{*}{ 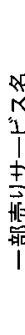 } & \multirow[t]{2}{*}{ 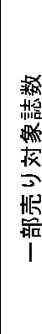 } & 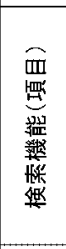 & 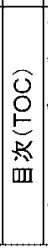 & 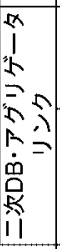 & $\frac{\Delta}{2}$ & 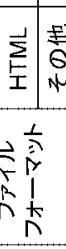 & 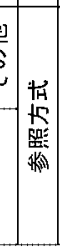 & 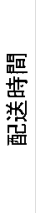 & \multirow[t]{2}{*}{ 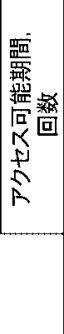 } & 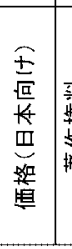 & 菜 & 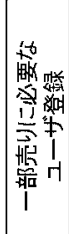 & \multirow[t]{2}{*}{ 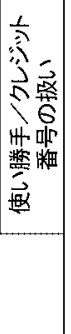 } & \multirow{2}{*}{ 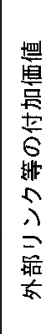 } & \multirow[t]{2}{*}{ 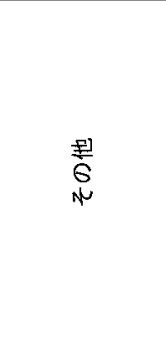 } \\
\hline & & & & & & & & & & & & 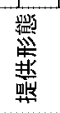 & & & & & 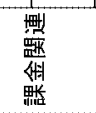 & & & \\
\hline
\end{tabular}


管理 Vol. 45 No. 11 February 2003

表1-2 出版社の一部売りサービス（つづき）

\begin{tabular}{|c|c|c|c|c|c|c|c|c|c|c|c|c|c|c|c|c|c|c|c|c|}
\hline$\tilde{s}$ & 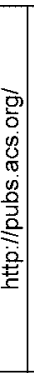 & 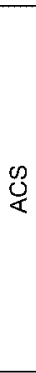 & 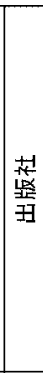 & 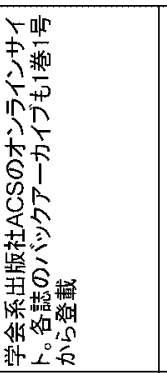 & 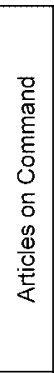 & 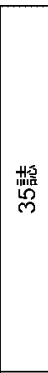 & 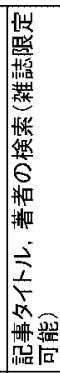 & 0 & 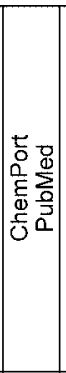 & 0 & $x$ & 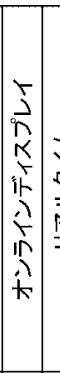 & 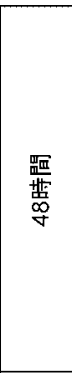 & 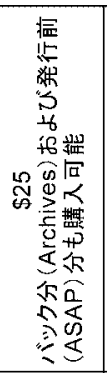 & I & 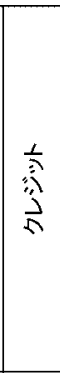 & $\overrightarrow{\not l}$ & 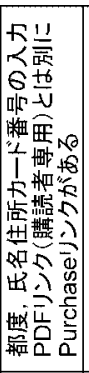 & ， & \multirow{2}{*}{ 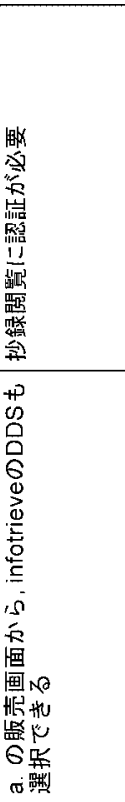 } \\
\hline$\frac{0}{\bar{\alpha}}$ & 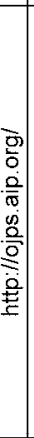 & $\frac{0}{<}$ & 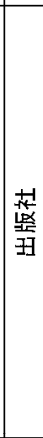 & 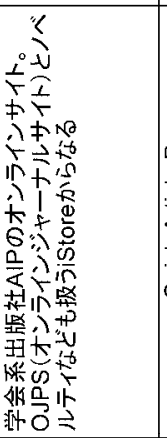 & 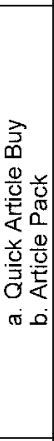 & 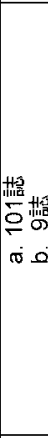 & 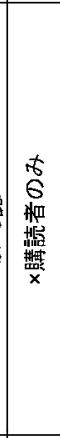 & 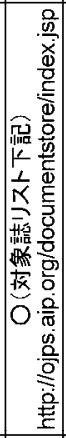 & 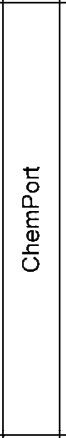 & 0 & 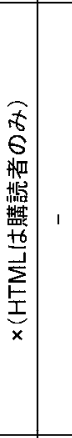 & 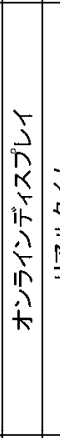 & 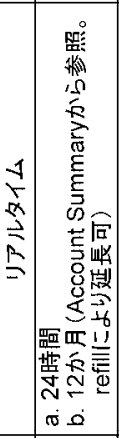 & 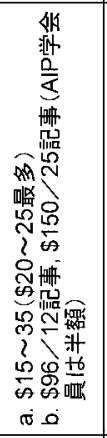 & & $\begin{array}{ll} \\
\\
\end{array}$ & 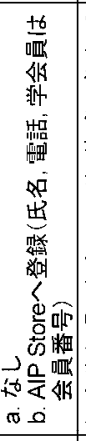 & 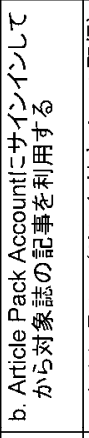 & 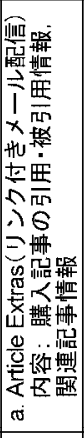 & \\
\hline 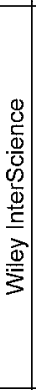 & 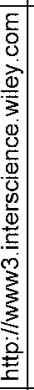 & 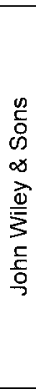 & 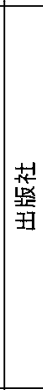 & 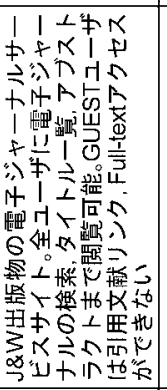 & 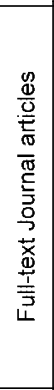 & 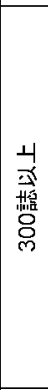 & 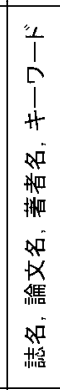 & $\mathrm{O}$ & 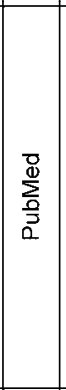 & 0 & 0 & 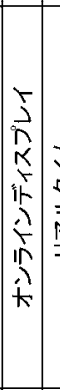 & 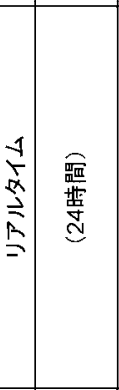 & 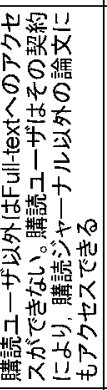 & ' & 1 & 1 & 1 & 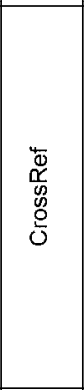 & 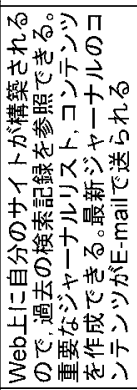 \\
\hline 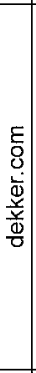 & 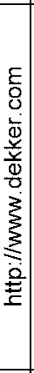 & 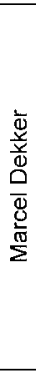 & 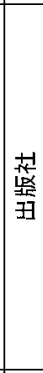 & 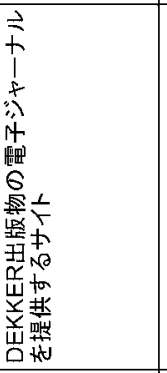 & 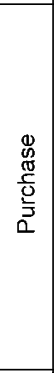 & 営 & 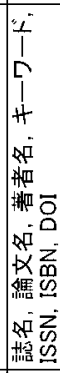 & 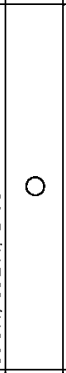 & $\begin{array}{l}\frac{\pi}{0} \\
\sum_{0}^{\frac{\pi}{3}} \\
0 \\
0\end{array}$ & 0 & 0 & 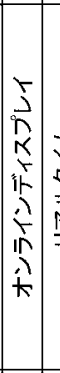 & 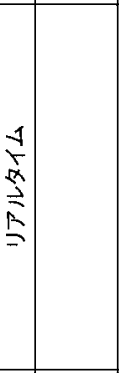 & 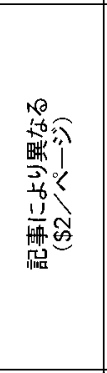 & 1 & 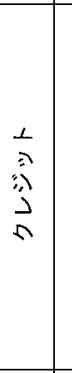 & 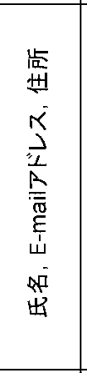 & 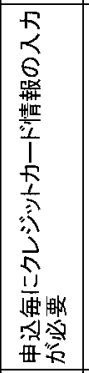 & $\begin{array}{l}\frac{4}{0} \\
\frac{1}{v} \\
w_{0} \\
\frac{0}{0}\end{array}$ & 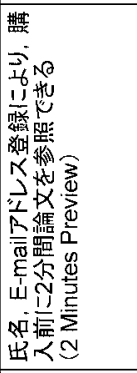 \\
\hline 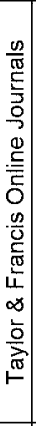 & 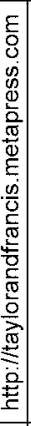 & 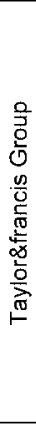 & $\mid$ & 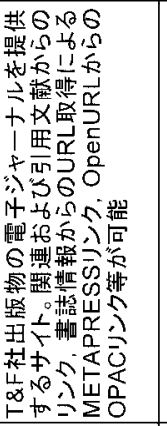 & 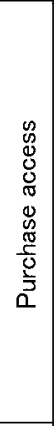 & 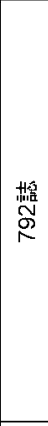 & 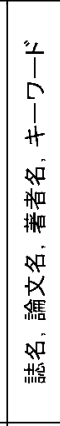 & 0 & 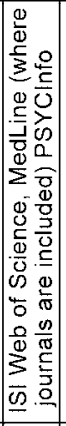 & 0 & $x$ & 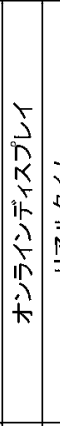 & 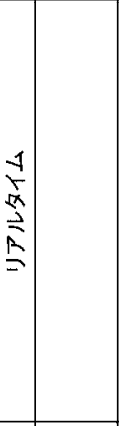 & 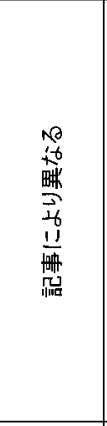 & & 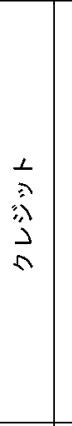 & 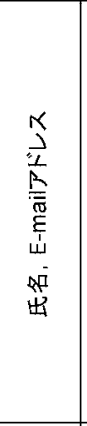 & 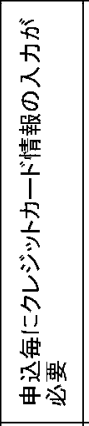 & 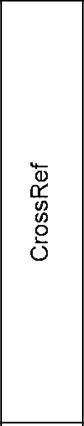 & 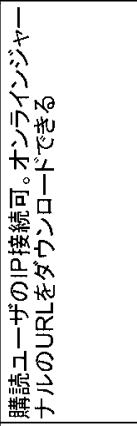 \\
\hline \multirow{2}{*}{\multicolumn{2}{|c|}{ 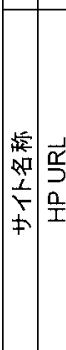 }} & \multirow[t]{2}{*}{ 些 } & & \multirow[t]{2}{*}{ 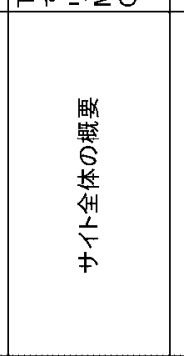 } & \multirow[t]{2}{*}{ 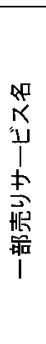 } & \multirow[t]{2}{*}{ 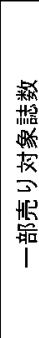 } & 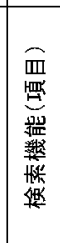 & $\begin{array}{l}\text { O } \\
\mathrm{O} \\
\text { 点 } \\
\text { 监 }\end{array}$ & 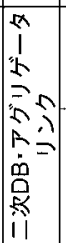 & 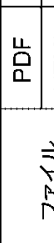 & 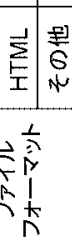 & 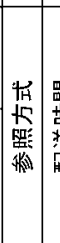 & 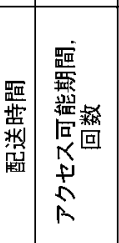 & 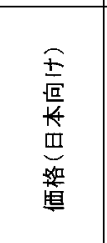 & 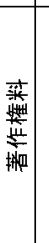 & 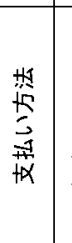 & 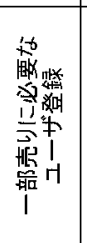 & 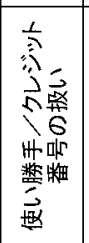 & \multirow{2}{*}{ 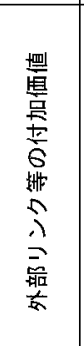 } & \multirow[t]{2}{*}{ 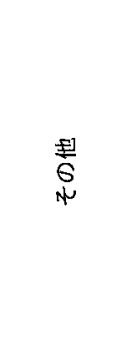 } \\
\hline & & & & & & & \multicolumn{3}{|c|}{ 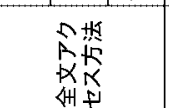 } & \multicolumn{4}{|c|}{ 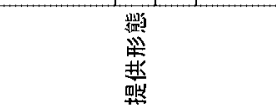 } & \multicolumn{5}{|c|}{ 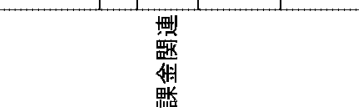 } & & \\
\hline
\end{tabular}


表2-1アグリゲータの一部売りサービス

\begin{tabular}{|c|c|c|c|c|c|c|c|c|c|c|c|c|c|c|c|c|c|c|c|c|c|}
\hline $\begin{array}{l}\stackrel{0}{0} \\
\sum_{0}^{\infty} \\
0 \\
0 \\
0 \\
0\end{array}$ & 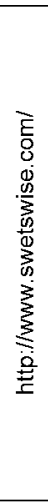 & 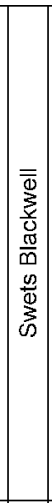 & 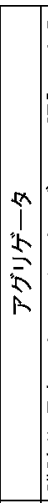 & 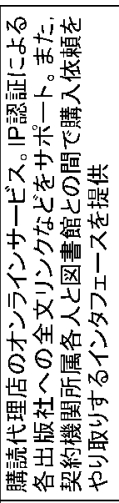 & $\begin{array}{l}\widehat{\hat{3}} \\
\frac{0}{3} \\
\frac{1}{0} \\
0 \\
\frac{1}{10} \\
\frac{0}{0} \\
0\end{array}$ & 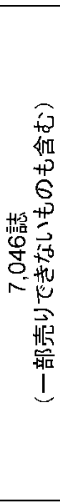 & 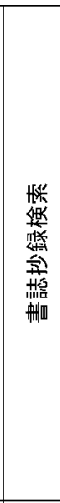 & 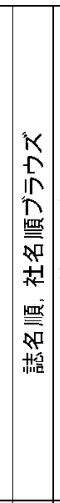 & 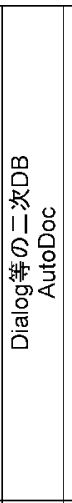 & 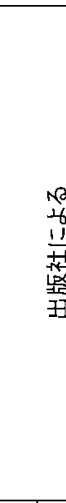 & 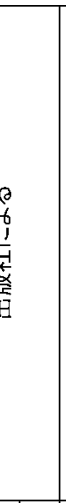 & & & 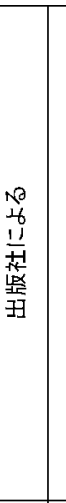 & 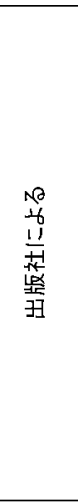 & 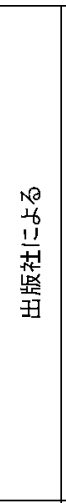 & 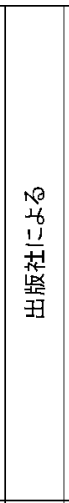 & 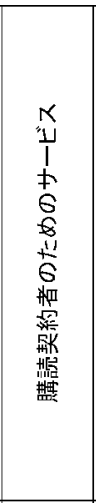 & 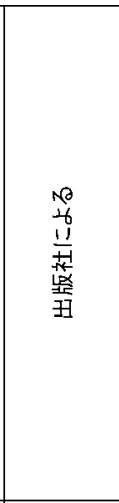 & 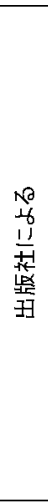 & 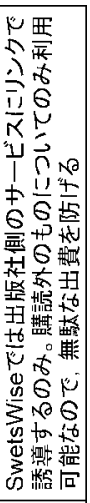 \\
\hline 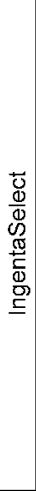 & 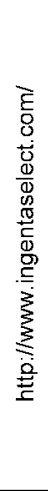 & 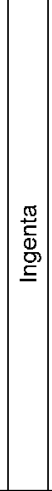 & 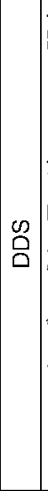 & 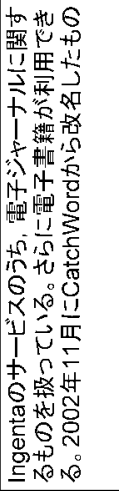 & 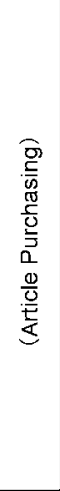 & 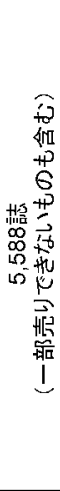 & 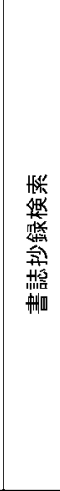 & 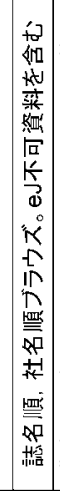 & 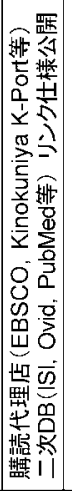 & 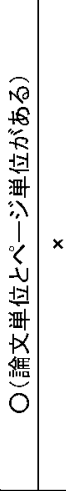 & 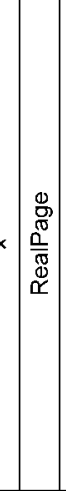 & 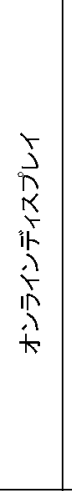 & 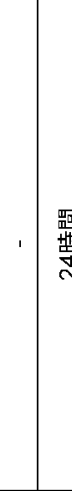 & 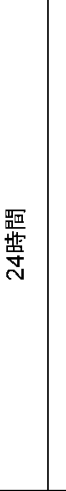 & 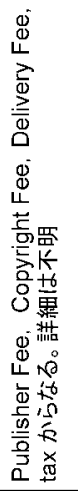 & 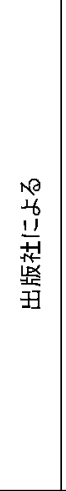 & 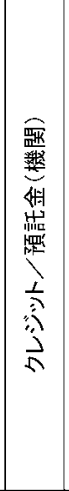 & 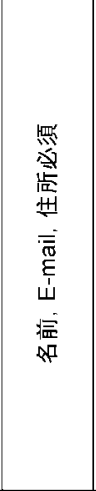 & 夢 & 賗 & ' \\
\hline 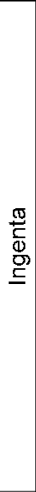 & 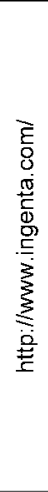 & 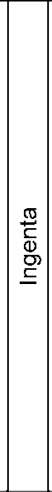 & : & 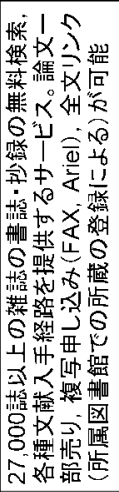 & 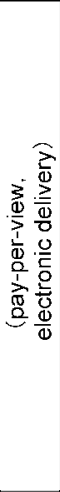 & 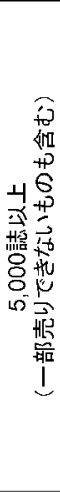 & 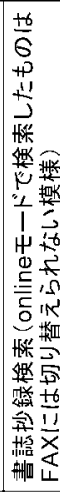 & 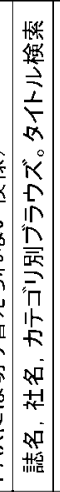 & 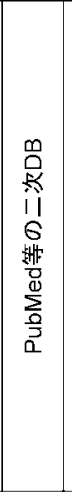 & $\mathrm{O}$ & 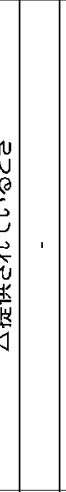 & 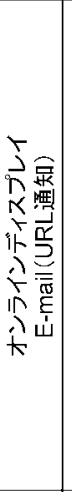 & 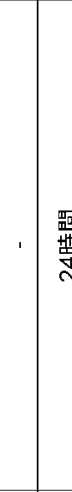 & 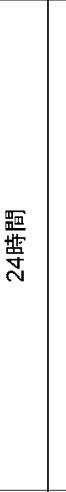 & 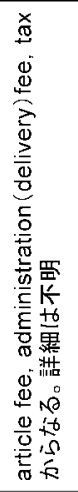 & 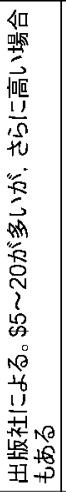 & 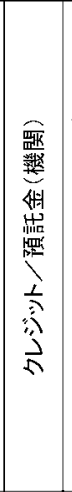 & 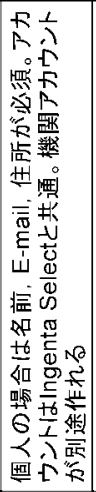 & 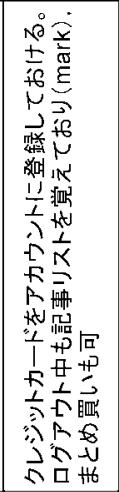 & $\begin{array}{l}\text { 爱 } \\
\text { 至 }\end{array}$ & 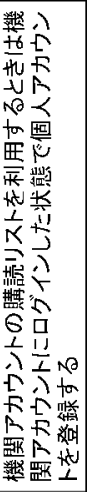 \\
\hline 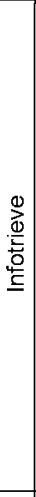 & 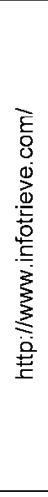 & 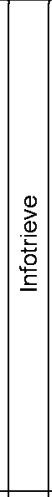 & $\begin{array}{l} \\
\text { की } \\
\text { की }\end{array}$ & 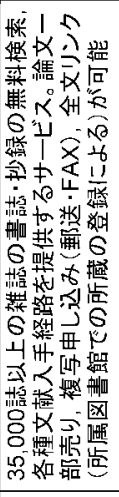 & 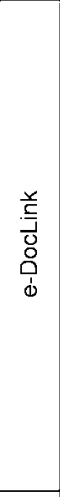 & 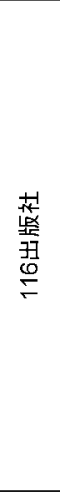 & 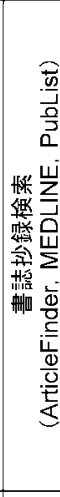 & 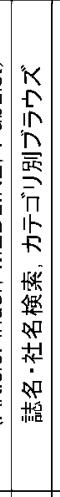 & 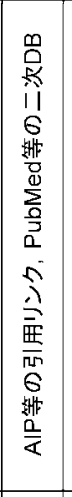 & $0 x$ & $\begin{array}{ll}x & 1\end{array}$ & 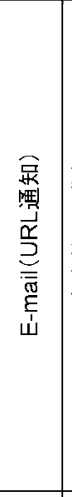 & 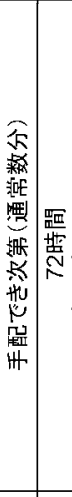 & 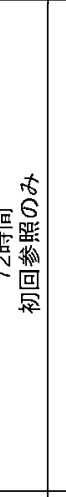 & 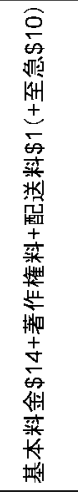 & 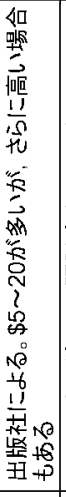 & 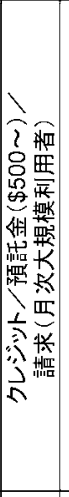 & 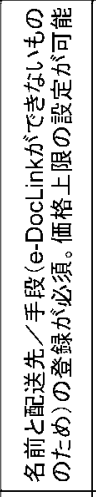 & 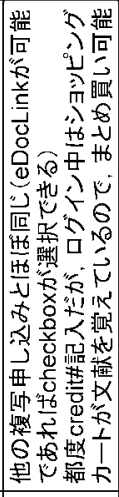 & $\overrightarrow{x \rightarrow b}$ & 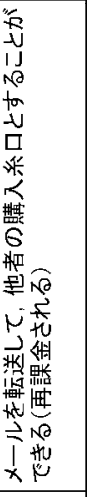 \\
\hline \multirow[t]{2}{*}{ 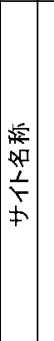 } & \multirow[t]{2}{*}{$\begin{array}{l}\overrightarrow{\underline{x}} \\
\frac{a}{\underline{I}}\end{array}$} & \multirow[t]{2}{*}{ 选 } & 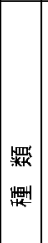 & \multirow[t]{2}{*}{ 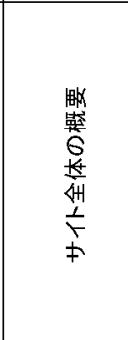 } & \multirow[t]{2}{*}{ 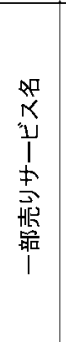 } & \multirow[t]{2}{*}{ 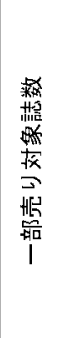 } & 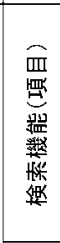 & 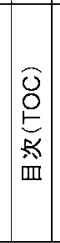 & 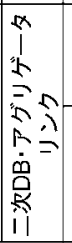 & 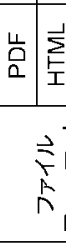 & 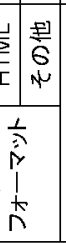 & 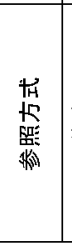 & 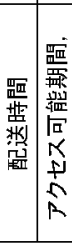 & 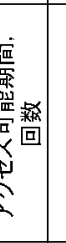 & 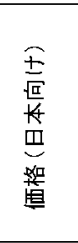 & 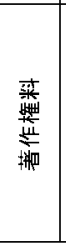 & $\begin{array}{l}\text { 热 } \\
\text { 点 } \\
\text { 焉 } \\
\text { 似 }\end{array}$ & 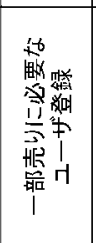 & 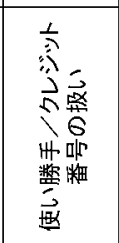 & \multirow{2}{*}{ 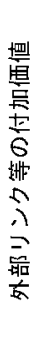 } & \multirow[t]{2}{*}{\begin{tabular}{l}
$\frac{ \pm}{6}$ \\
\multirow{2}{*}{}
\end{tabular}} \\
\hline & & & & & & & & 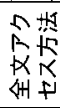 & & & & 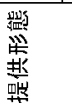 & & & & & & & & & \\
\hline
\end{tabular}


管理 Vol. 45 No. 11 February 2003

表2-2アグリゲータの一部売りサービス（つづき）

\begin{tabular}{|c|c|c|c|c|c|c|c|c|c|c|c|c|c|c|c|c|c|c|c|c|c|}
\hline 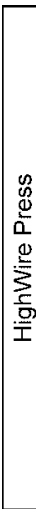 & 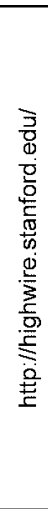 & 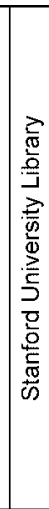 & 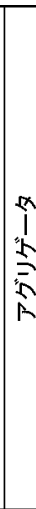 & 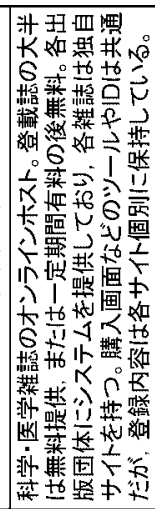 & $\begin{array}{l}\widehat{3} \\
\frac{0}{3} \\
\frac{1}{0} \\
0 \frac{1}{1} \\
\frac{1}{0} \\
0\end{array}$ & 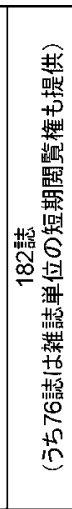 & 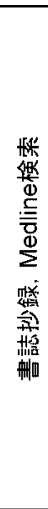 & 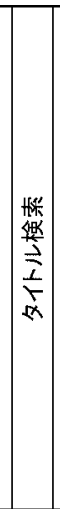 & 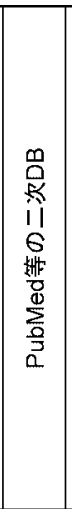 & 010 & 0 & 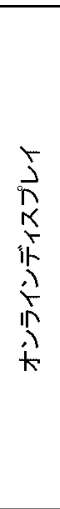 & & 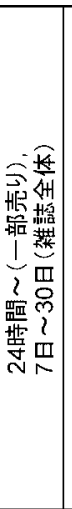 & 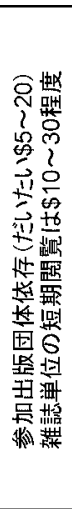 & 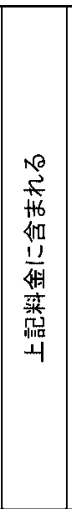 & 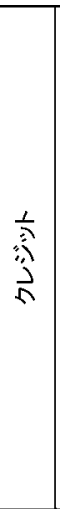 & 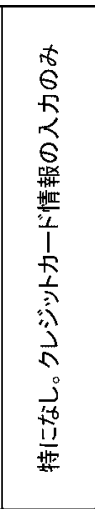 & 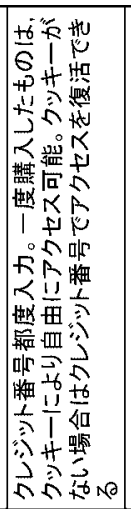 & 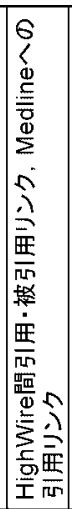 & \\
\hline 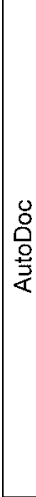 & 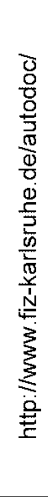 & 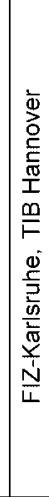 & م0 & 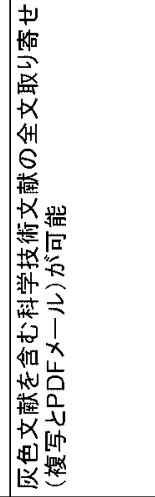 & 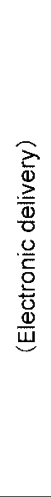 & 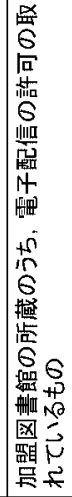 & $\vec{x}$ & $\vec{x}$ & 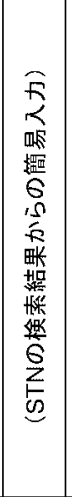 & $0 x$ & $x$ & 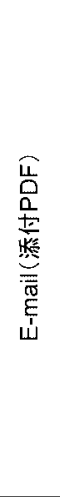 & 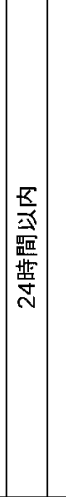 & 高 & 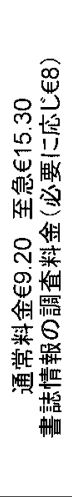 & 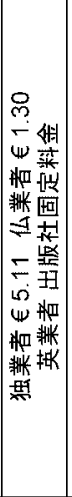 & 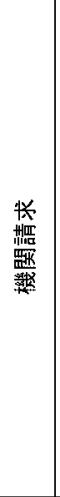 & 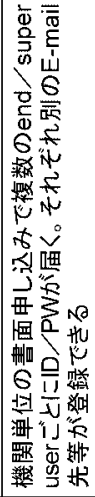 & 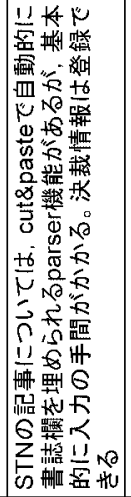 & . & 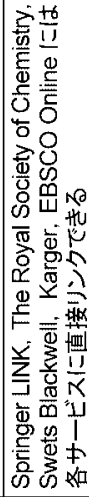 \\
\hline 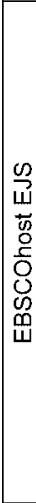 & 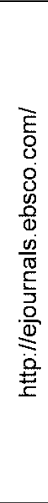 & 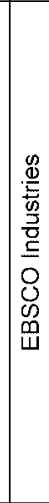 & 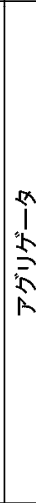 & 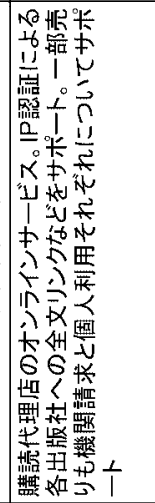 & 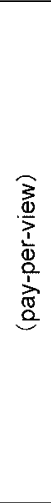 & 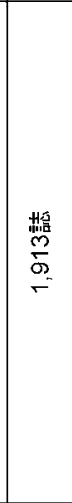 & 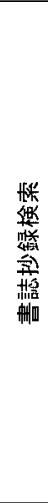 & 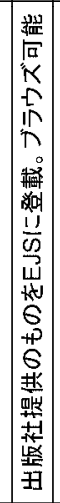 & 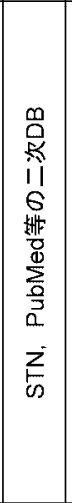 & $0 x$ & $x$ & 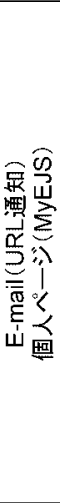 & & 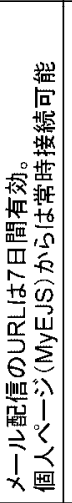 & 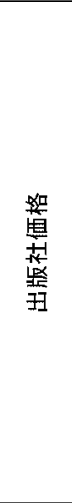 & 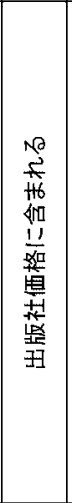 & 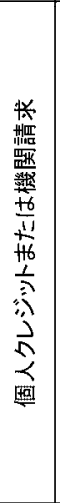 & 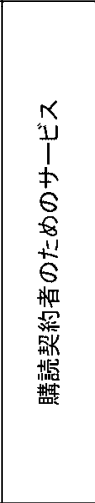 & 夢 & $\vec{t}+\frac{1}{10}$ & \\
\hline \multirow[t]{2}{*}{ 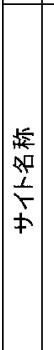 } & \multirow[t]{2}{*}{$\begin{array}{l}\overrightarrow{\vec{\alpha}} \\
\stackrel{\vec{J}}{ } \\
\frac{0}{1}\end{array}$} & \multirow{2}{*}{\multicolumn{2}{|c|}{ 些 }} & \multirow{2}{*}{ 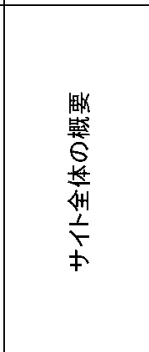 } & \multirow[t]{2}{*}{ 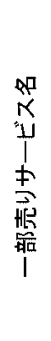 } & \multirow{2}{*}{ 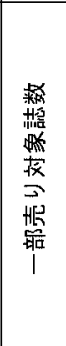 } & 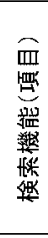 & 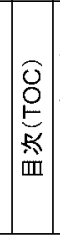 & 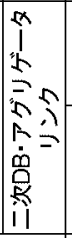 & 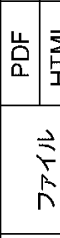 & 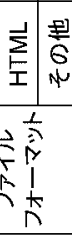 & 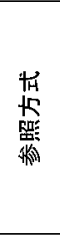 & 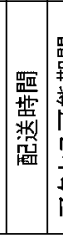 & 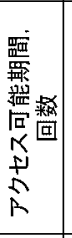 & 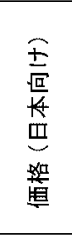 & 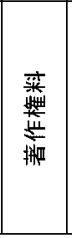 & 热 & 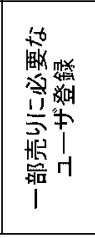 & 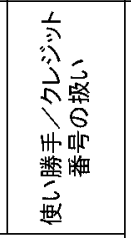 & \multirow{2}{*}{ 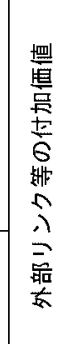 } & \multirow[t]{2}{*}{$\underset{N}{\stackrel{p}{*}}$} \\
\hline & & & & & & & & 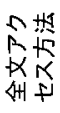 & & & & 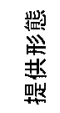 & & & & & & 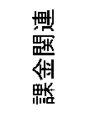 & & & \\
\hline
\end{tabular}


表3 二次データベースの一部売りサービス

\begin{tabular}{|c|c|c|c|c|c|c|c|c|c|c|c|c|c|c|c|c|c|c|}
\hline & 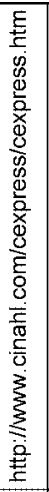 & 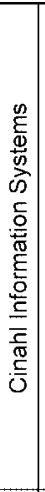 & & 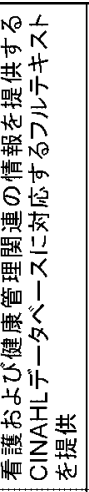 & & 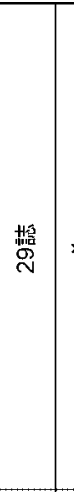 & $\times 0$ & $\times$ & 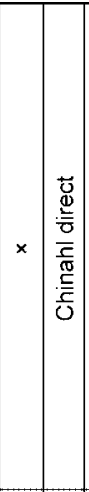 & $0 \times$ & 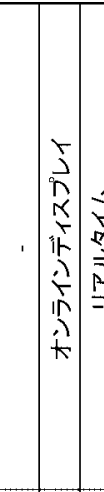 & 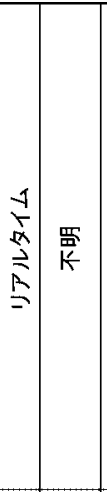 & ' & 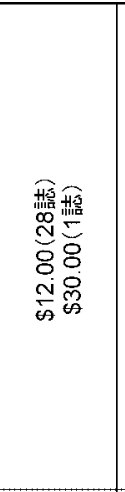 & 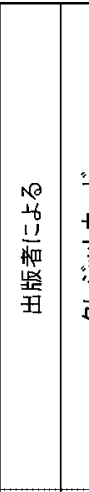 & 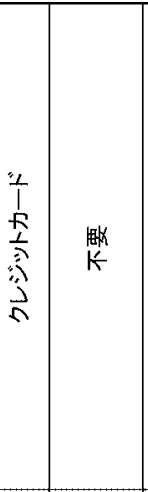 & & \\
\hline & 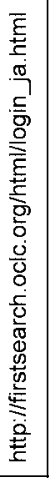 & $\begin{array}{l}0 \\
\vec{d} \\
0\end{array}$ & & 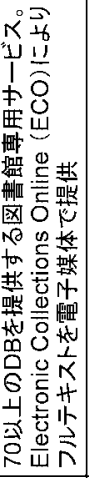 & 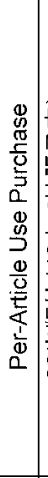 & 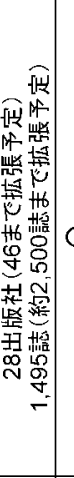 & 0 & $\times$ & 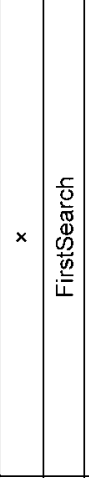 & $\circ \triangleleft$ & 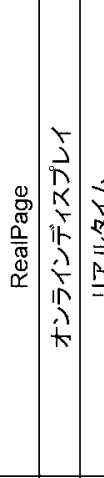 & 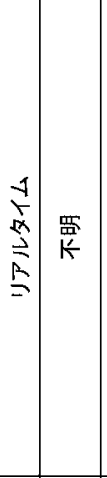 & 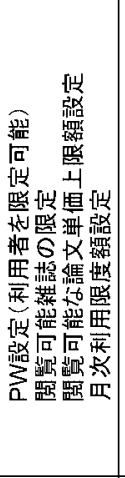 & 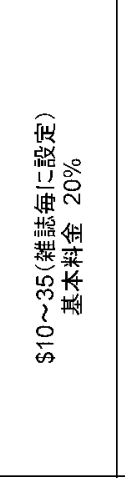 & 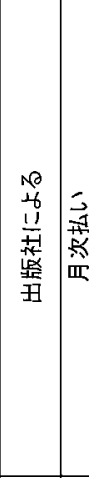 & 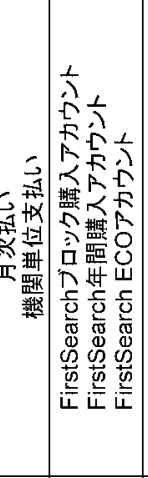 & 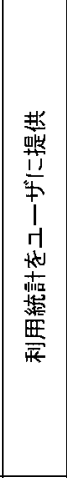 & \\
\hline & 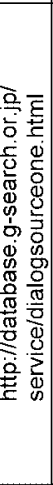 & & . & 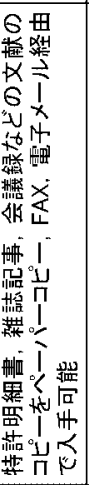 & 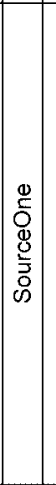 & $\begin{array}{l}\text { 爱 } \\
\text { F }\end{array}$ & \begin{tabular}{l|l}
$\times$ & $x$
\end{tabular} & $x$ & 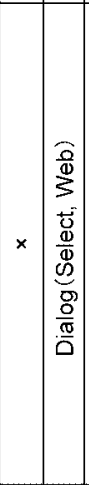 & $0 \times$ & 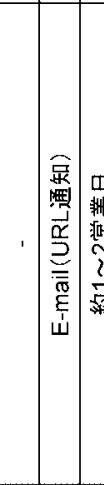 & 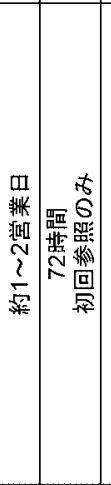 & ' & 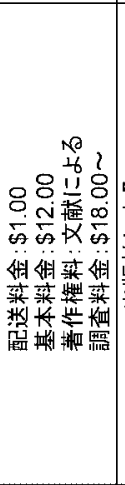 & 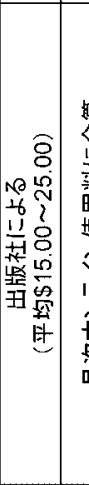 & 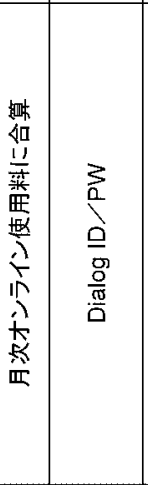 & & \\
\hline & 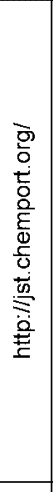 & J్ & & 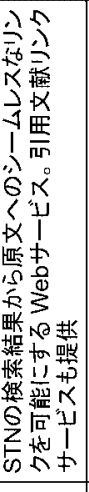 & 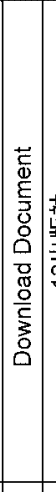 & 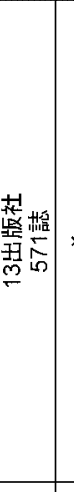 & \begin{tabular}{l|l}
$x$ & $x$
\end{tabular} & 0 & 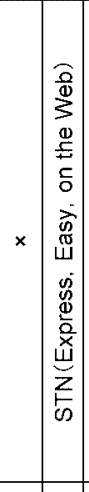 & 0 & 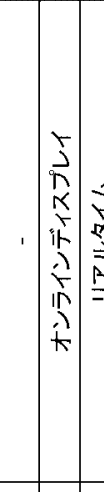 & 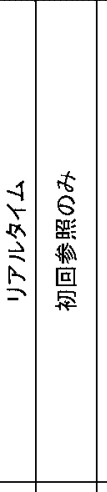 & $x$ & 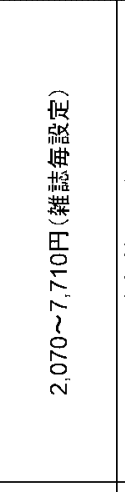 & 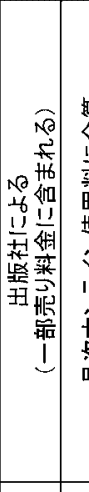 & | & 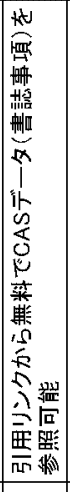 & 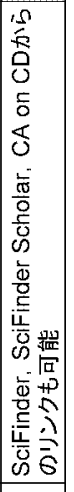 \\
\hline & \multirow[t]{2}{*}{$\begin{array}{l}\frac{1}{3} \\
\frac{1}{I} \\
\frac{1}{1}\end{array}$} & & \multirow{2}{*}{\multicolumn{2}{|c|}{ 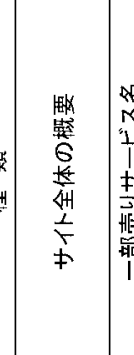 }} & \multirow[t]{2}{*}{. } & 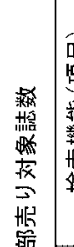 & 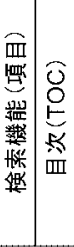 & 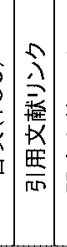 & 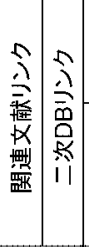 & 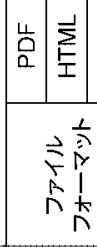 & 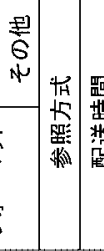 & 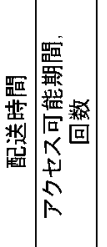 & 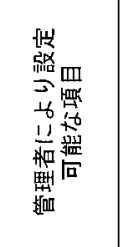 & 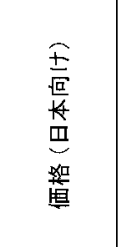 & 焉 & 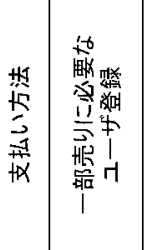 & \multirow[t]{2}{*}{ 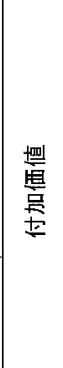 } & \multirow[t]{2}{*}{$\begin{array}{l}\text { 全 } \\
\text { r }\end{array}$} \\
\hline & & & & & & & & 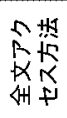 & & & & 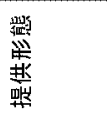 & & & & & & \\
\hline
\end{tabular}


管理 Vol. 45 No. 11 February 2003

表4 料金比較

\begin{tabular}{|c|c|c|c|c|c|c|c|c|c|c|c|c|c|c|c|c|c|c|c|c|}
\hline 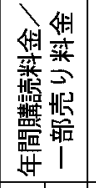 & बे) & $\begin{array}{l}q \\
\end{array}$ & 吕 & $g$ & 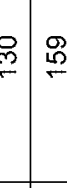 & ర్ల & 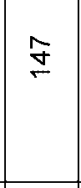 & 암 & סू & 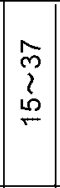 & 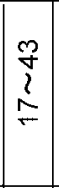 & \begin{tabular}{l}
$\hat{0}$ \\
$\stackrel{2}{?}$ \\
\multirow{y}{y}{}
\end{tabular} & L) & 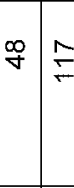 & $=\mathbb{N}$ & $\begin{array}{l}2 \\
0 \\
2 \\
5 \\
5\end{array}$ & 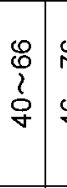 & & 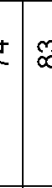 & 9 \\
\hline 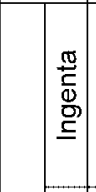 & & & 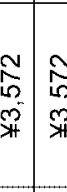 & 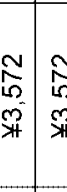 & 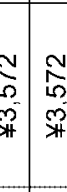 & 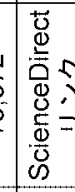 & 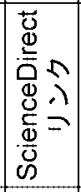 & 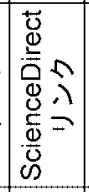 & 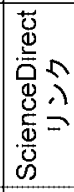 & ' & & ' & 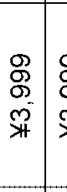 & 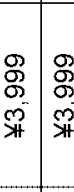 & 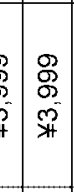 & ' & ' & & & \\
\hline 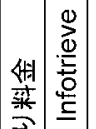 & 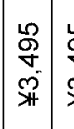 & 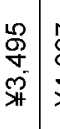 & 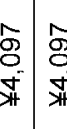 & 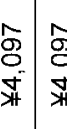 & 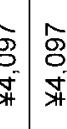 & & & ' & ' & 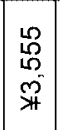 & 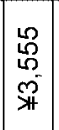 & 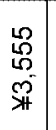 & $\begin{array}{ll}\hat{\tilde{y}} & \\
\vdots \\
\vdots \\
\forall\end{array}$ & 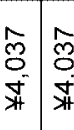 & 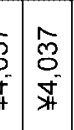 & \begin{tabular}{l}
$\overline{8}$ \\
$\dot{6}$ \\
\hdashline
\end{tabular} & $\begin{array}{l}\overline{8} \\
\overline{8} \\
\underbrace{\circ}\end{array}$ & 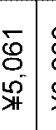 & 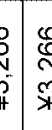 & \\
\hline 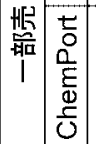 & 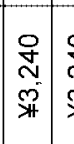 & 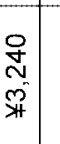 & & ' & ' & ' & ' & ' & ' & 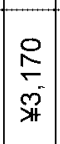 & 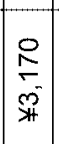 & 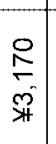 & & ' & ' & ' & ' & ' & & \\
\hline 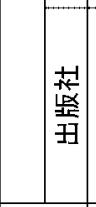 & 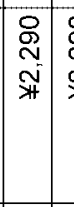 & 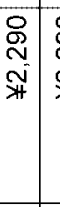 & 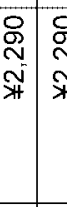 & 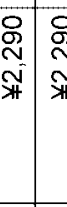 & 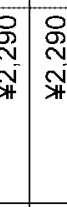 & 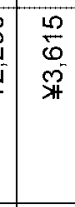 & 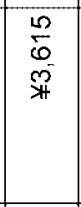 & 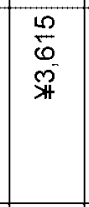 & $\begin{array}{l}\frac{n}{2} \\
0 \\
\pi \\
\pi\end{array}$ & 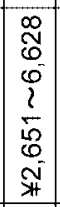 & 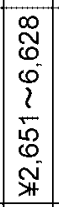 & 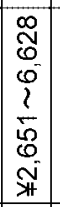 & 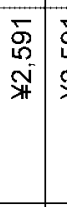 & 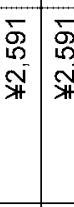 & 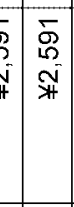 & 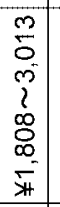 & 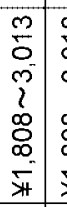 & 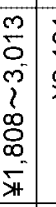 & & \\
\hline 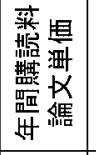 & 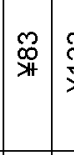 & $\underset{\nabla}{\mathbb{N}}$ & 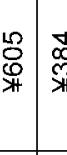 & 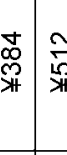 & 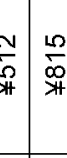 & 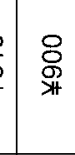 & 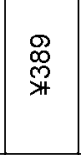 & 寄 & 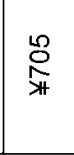 & 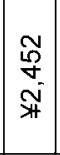 & 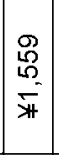 & 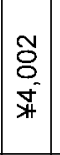 & 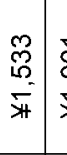 & 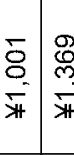 & 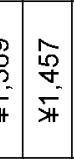 & $\frac{\bar{\sigma}}{\bar{*}}$ & 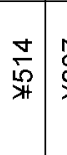 & 空 & & \\
\hline 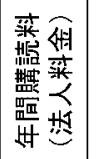 & 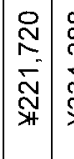 & 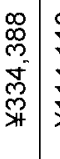 & 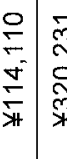 & 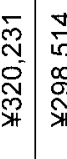 & 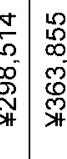 & 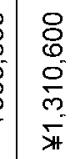 & 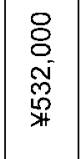 & 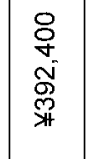 & \begin{tabular}{l}
8 \\
0 \\
0 \\
$\infty$ \\
$o$ \\
\hdashline \\
$¥$
\end{tabular} & \begin{tabular}{l}
$\widehat{o}$ \\
0 \\
0 \\
0 \\
\hdashline
\end{tabular} & 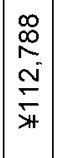 & 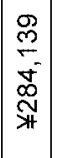 & 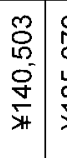 & 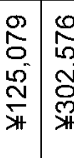 & 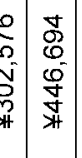 & 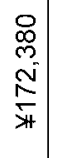 & 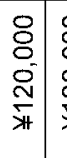 & \begin{tabular}{c|c}
8 & \\
0 \\
0 \\
$m$ & \\
$*$ &
\end{tabular} & 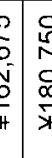 & 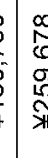 \\
\hline 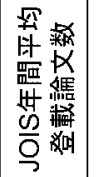 & 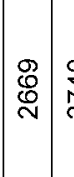 & 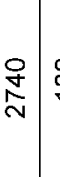 & 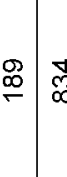 & 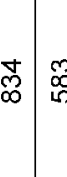 & 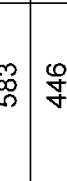 & 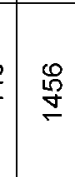 & $\begin{array}{l}\mathscr{్} \\
\stackrel{్}{-}\end{array}$ & 导 & চூ & $q$ & $\mathbb{N}$ & $\bar{n}$ & $\delta$ & $\stackrel{\mathscr{N}}{\stackrel{N}{N}}$ & $\bar{N} \mid \hat{S}$ & \%े & ్ָ & $\Sigma$ & ğ & $c_{\infty}^{g}$ \\
\hline 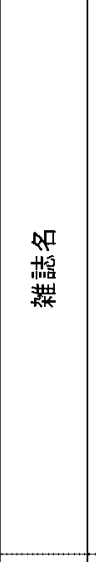 & 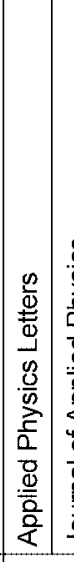 & 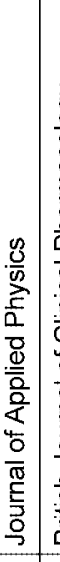 & 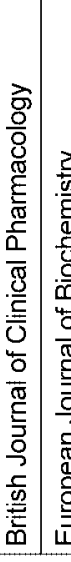 & 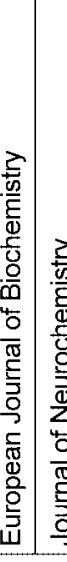 & 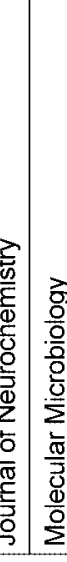 & 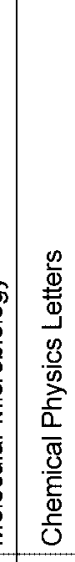 & 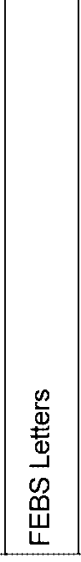 & 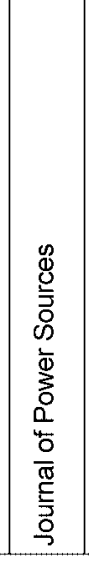 & 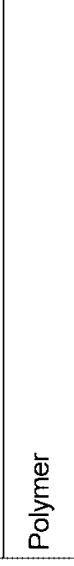 & 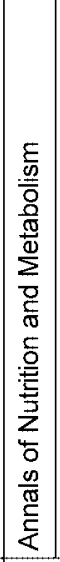 & 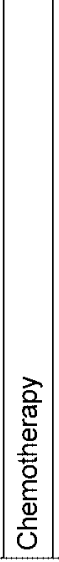 & 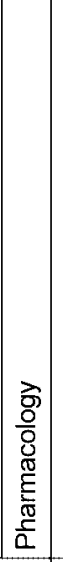 & 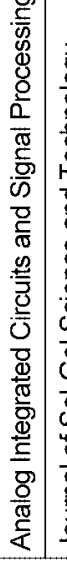 & 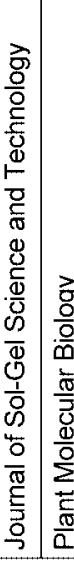 & 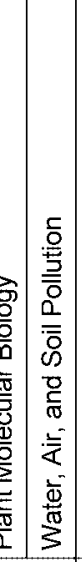 & $\begin{array}{l}\frac{1}{\underline{\underline{z}}} \\
\frac{\mathbb{\pi}}{2} \\
\end{array}$ & 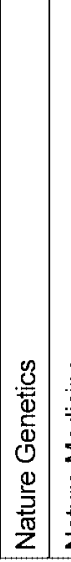 & 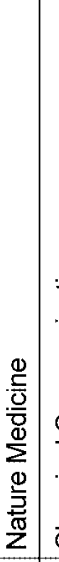 & 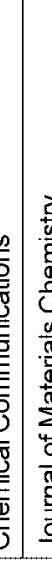 & 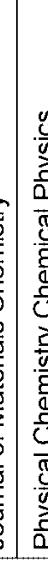 \\
\hline $\begin{array}{l}\text { 茙 } \\
\text { 焉 }\end{array}$ & 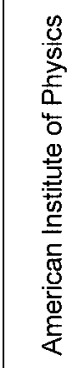 & & & 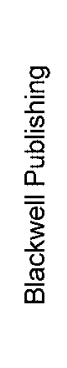 & & & & 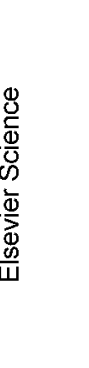 & & & 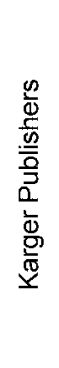 & & & 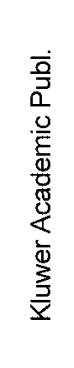 & & & 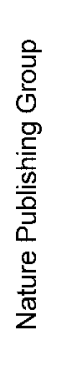 & & & \\
\hline
\end{tabular}

